\title{
WOMEN IN A DUAL BOARD SYSTEM AND DIVIDEND POLICY
}

\author{
Tastaftiyan Risfandy*, Timotius Radika**, and Leo Indra Wardhana*** \\ ${ }^{*}$ Corresponding author. Faculty of Economics and Business \& Center for Fintech and Banking, Universitas \\ Sebelas Maret, Indonesia. Email: tastaftiyan.risfandy@staff.uns.ac.id \\ ${ }^{* *}$ Faculty of Economics and Business, Universitas Sebelas Maret, Indonesia. \\ Email: timotiusradika@gmail.com \\ ***Department of Economics and Business Vocational School, Universitas Gadjah Mada, Indonesia. \\ Email: leo.wardhana@ugm.ac.id
}

\begin{abstract}
We investigate whether female presence on firms' board of commissioners and board of directors is associated with a higher dividend policy. Using panel data on 525 publicly listed firms in Indonesia between 2011 and 2018, we find that the impact of females' presence on firms' boards on dividend policy depends on their role as either an executive or a non-executive on the boards. Female directors are negatively associated with cash dividend payments, while female commissioners are positively associated with dividend payments in the case of only family-controlled firms. Our results provide insights into corporate governance practices in a two-tiered board system in a developing country.
\end{abstract}

Keywords: Board of commissioners; Board of directors; Dividend policy; Gender diversity; Dual board system.

JEL Classifications: D04; G34; J16.

Article history:

Received : September 21, 2020

Revised : December 4, 2020

Accepted : December 7, 2020

Available Online: January 31, 2021

https://doi.org/10.21098/bemp.v24i0.1465 


\section{INTRODUCTION}

Over the past decade, the issue of board gender diversity has attracted great attention, as indicated by the increasing number of women on corporate boards, especially in developed countries, such as those in Western Europe (Smith, 2018) and the US (Solal \& Snellman, 2019). Data from the Organization for Economic Cooperation and Development member countries on the proportion of women on the boards of the largest listed companies show an increasing trend across countries. ${ }^{1}$ Studies have shown that gender diversity has a substantial role in corporate policies that positively value organizational performance. Female members of boards of directors (BODs) tend to be more active in attending company meetings, obey rules and laws, are more sensitive to ethical issues, take different perspectives on decision making, are more risk-averse, and are communicative in solving problems (Bernardi \& Arnold, 1997; Adams \& Ferreira, 2009; Price, 2012; Cumming et al., 2015). Bernile et al. (2018) show that board gender diversity affects corporate policies as reflected in better corporate performance. Hence, female directors can be better at representing shareholder interests, especially the minority shareholders, as well as balancing the interest of all stakeholders. Therefore, the presence of a female board member serves as a governance mechanism that reduces agency problems. On the other hand, the literature also shows that dividend has been used as an effective tool to reduce agency problems (La Porta et al., 2000), while dividend decisions, like other strategic firm decisions, are decided by BODs, who are expectedly representing the best interest of the shareholders. This article explores board gender diversity and its impact on firms' dividend policy in an emerging country, Indonesia.

Indonesia is a predominantly patriarchal society, except in a few communities (AIPEG, 2017). Indonesia's population is also an overwhelmingly Muslim, by religious affiliation, which heavily influences socio-cultural life in the country (Sakai \& Fauzia 2016). Islamic doctrine holds that women's place is in the home, whereas men are responsible for work outside the home, which is reflected in Indonesia's Family Law (1974). In Indonesian culture, the social norm is that the husband provides for his wife and the family, although it is socially acceptable for women to be involved in informal economic activity. Therefore, under all circumstances, women should not lead men. In Indonesia, women have more difficulty than men in getting a job, and they have less access to more lucrative positions and receive on average about 70 percent of the men's wages in the formal sector and 50 percent in the informal sector (AIPEG, 2017). A policy brief on gender equality by the Ministry of National Development Planning and the Ministry of Women Empowerment and Child Protection of Indonesia (2011) shows that women's participation in the formal economy is mostly limited by their traditional role in taking care of the family at home, poor access to formal sector employment, culturally defined expectations of appropriate work for women, and discriminatory practices at work. That being the case, the effect of women's presence on the firm board will possibly have an impact on dividend payment in the Indonesian context that is likely different from what has been found in the previous studies.

1 See OECD.Stat (https://stats.oecd.org/index.aspx?queryid=54753/). 
Moreover, the investigation of the nexus between female's presence and dividend policy is important because only a few studies examine how female directors influence dividend policies. For instance, Byoun et al. (2016), Chen et al. (2017), and Benjamin and Biswas (2019) focused on the US firms, but these firms have a one-tiered system. In such a system, both managerial and supervisory functions are in a unified board. Consequently, the issue of CEO duality exists and might reduce the role of monitoring. In this case, female directors play an essential role in reducing the adverse effects of CEO duality, as female directors are considered to have more monitoring capacity (Wang et al., 2019). For dividend policy, the aforementioned studies found a positive relationship between female directors and dividend payments, which is an example of female directors promoting better corporate governance in the context of CEO duality issue.

This paper is also different from prior empirical works because, unlike firms in most countries, Indonesian firms have a two-tiered system, with both a board of commissioners (BOC) and a BOD. This system, regulated by the Limited Liability Law (2007), explicitly separates the role of executives and non-executives. This mechanism differs from a one-tiered system in which executives hold a position on the board. Therefore, CEO duality (or CEOs who are also BOD chairs) does not exist in Indonesia, which implies that female directors' role in dividend policy in a two-tiered system might be different, depending on which board they serve. Nevertheless, investigating women's role in the two-tier system will be more complicated as it will have to cover the boards in both tiers, the supervisory and the managerial or executive function; the question then is in which roles or functions do women contribute more to dividend policy? To answer this question, this article investigates the impact of gender diversity among both commissioners and directors on dividend payment policy. Meanwhile, few studies have been conducted on female directors in a two-tiered system (Pucheta-Martínez \& Bel-Oms 2015), especially in developing countries, where, despite significant economic growth, female participation in the labor force is relatively low, as is the level of gender diversity on BODs (Darmadi, 2010; 2011). Saeed and Sameer (2017) examined the issue for developing countries with a two-tiered system, but their cross-country study does not investigate the two types of boards separately. In addition, different cultural and ethical environments affect gender roles in general (Amore et al., 2014; Deng, 2015; Cho et al., 2019).

To see how women's presence on Indonesian firms' boards affects dividend policy, we use a sample of 525 publicly listed firms in Indonesia between 2011 and 2018. We define dividend policy in terms of both the amount of cash dividends and the propensity to pay dividends, following prior studies such as Fama and French (2001), Francis et al. (2011), Dewasiri et al. (2019), and Ye et al. (2019). Regarding the female presence on the board, we separately investigate women's roles in the $\mathrm{BOD}$ and BOC, because the executive and non-executive roles in the Indonesian two-tier system are explicitly separated. Following Gul et al. (2011), Ye et al. (2019), and Chen et al. (2017), women's presence is proxied by the number of female board members, the natural logarithm of the number of female board members plus one, and the proportion of female board members. Several control variables are also introduced in this study to avoid omitted variable bias. 
In this paper, we also investigate the role of female directors in the familyowned businesses with a dual board structure, which is also unexplored in the literature. In Indonesia, most listed firms are controlled by a family (Claessens et al., 2000), whereby board members are usually appointed by the head of the family to ensure their interests are protected (Yoshikawa \& Rasheed, 2010). Therefore, trusted family members commonly serve as board members, in either the executive or supervisory function, or both. In such a context, understanding whether or not the positive attribute of female directors persist is crucial, considering businesses in Asian countries follow the social value and preserve the role of gender (Yan \& Sorenson, 2004; Deng, 2015).

Our empirical evidence suggests that female commissioners' presence is not related to dividend policy, while the existence of female directors in a firm has a negative effect on dividend payment. These results suggest that women have a greater role in firms' dividend policy if they have a role as an executive. More specifically, female directors have a precautionary motive to lower cash dividend distribution to retain more cash on hand as a buffer for unpredictable situations in the future. Prior studies also report that female directors are not as confident as male directors when making corporate decisions (Huang \& Kisgen, 2013) and are less risk-tolerant than male board members (Levi et al., 2014). In the subsequent analysis, however, female commissioners are negatively associated with cash dividend payment at family-controlled firms but not at non-familycontrolled firms. This finding suggests that female commissioners are actively involved in cash dividend decisions at family-controlled firms, indicating that female commissioners prefer to have more buffers to ensure the family-controlled business's long-term sustainability (Prencipe et al., 2011). Overall, our result supports prior studies, such as Saeed and Sameer (2017), suggesting a different dividend policy in an emerging country with high business risk, a more volatile stock market, and high inflation.

This paper offers a significant contribution to the literature because, to the best of our knowledge, this is the first study to examine the role of gender in promoting dividend payment and reducing agency conflicts in firms in developing countries with a two-tiered system. Most prior empirical studies are conducted using samples from developed countries with a one-tiered system, such as Russia (Saeed and Sameer, 2017) and Spain (Pucheta-Martínez \& Bel-Oms, 2015). Other studies either examine emerging countries, such as Sri Lanka (Dewasiri et al., 2019) and India (Sanan, 2019) or a worldwide sample of countries (Benjamin and Biswas, 2019; Chen et al., 2017; Ye et al., 2019). However, an empirical study using a sample from a single country could capture the phenomena that cannot be observed by using samples from multiple countries. This study also provides empirical evidence on the separate impacts of supervisory and executive roles on corporate strategic decisions such as dividend policy. Most prior studies focus on the impact of female directors on financial performance and only a few studies examine the impact on dividend policies. Again, the few existing papers, such as Byoun et al. (2016), Chen et al. (2017), and Benjamin and Biswas (2019), focus on US firms with a one-tiered system, but little empirical research has been done on a two-tiered system. 
The rest of the paper is organized as follows. Section II develops the hypotheses. Section III describes the research method, the sample selection, and empirical models. Section IV presents the results and robustness checks. Section $\mathrm{V}$ concludes.

\section{HYPOTHESIS DEVELOPMENT}

The literature on corporate governance suggests that dividends are an effective tool for managing agency conflicts, particularly free-cash-flow problems, between managers and shareholders as well as between majority and minority shareholders (Rozeff, 1982; Easterbrook, 1984; Jensen, 1986). La Porta et al. (2000) and Brockman and Unlu (2009) provide empirical evidence that investor protection matters in shaping firms' dividend policies around the world. In the same spirit, Bøhren et al. (2012), Ngo et al. (2018), and Balachandran et al. (2019) find that controlling shareholders tend to use dividend policy to mitigate conflicts with minority shareholders. In studying female directors, Kang et al. (2010) provide evidence that women place more interest in protecting shareholders, a finding that is recently supported by Srinidhi et al. (2020), who show that the presence of female board members is beneficial to firm governance. The positive impact of women's presence on boards is possibly because they have distinct characteristics compared to their men colleagues that could enhance strategic decision-making, particularly at the top of the corporate hierarchy. According to Adams and Funk (2012), female directors care more about benevolence and stimulation. On the other hand, male directors are more achievement- and power-oriented than the female Adams (2016). This evidence is consistent with some empirical works suggesting that women generally exhibit less willingness than men to engage in competitive activities and men, in contrast, have better performance when subject to competitive pressure (Amore et al., 2014). Therefore, if some of these distinct values are combined in a board, they could complement each other. Female commissioners also tend to pay more attention to the welfare of shareholders (Liu, 2018) and this could be an implementation of the benevolence value. Because the role of women in Indonesia, particularly in the firm and in the government, is also increasing, we posit that. $\mathbf{H}_{\mathbf{1}}$ : In a two-tiered system, females' presence on the board of commissioners is positively associated with dividend payment policy.

The top management team's composition can be a signal to investors regarding a firm's future performance (Quintana-García \& Benavides-Velasco, 2016). Unlike with diversity among commissioners, we argue that the gender diversity in the board of directors' membership will have a negative impact on the dividend payment policy of a firm because the literature provides evidence that women are more risk-averse and have lower overconfidence than men. Appointing woman executives can reduce the likelihood of excessive risk-taking, since women are more likely to show risk aversion in financial decisions (Jianakoplos \& Bernasek, 1998), leading to less risky corporate outcomes (Adams, 2016). Levi et al. (2014) document that more gender-diverse boards are associated with lower deal initiation activity, implying that more diverse boards are less overconfident. A top management team with more female representation also exhibits more conservative behaviour than a non-diverse team (Baixauli-Soler et al., 2015). Consequently, female directors 
tend to hold on to more excess cash flow by not paying dividends because they are afraid of unstable future financial conditions (Saeed \& Sameer, 2017). Huang and Kisgen (2013) report that female executives make fewer investment decisions than male executives. Although some prior studies report that female executives have significantly higher financial performance, this occurs only in markets with low competition (Amore and Garofalo, 2016). Moreover, in a Muslim-majority population such as in Indonesia, women's presence might not be accepted in all fields and it could decrease the willingness of women to make risky decisions in the organization they participate in. Subsequently, we hypothesize that their presence among top-level management or BODs will deteriorate the firm's decision-making process, including dividend payments. That is,

$\mathbf{H}_{2}$ : In a two-tiered system, females' presence on the board of directors is negatively associated with dividend payment policy.

\section{DATA AND METHODOLOGY}

\section{A. Data and sample}

We use a sample of listed companies in Indonesia from 2011 to 2018. The sample period is restricted to 2011-2018 to avoid the crisis period that could have changed firms' behavior towards their dividend policies. Our data come from the OSIRIS database and the Indonesian Capital Market Directory. We take all firms available from the database as our sample, since we observe dividend policies that are more driven by the controlling shareholders rather than stock liquidity. Following prior research on dividend policy (Fama \& French, 2001; DeAngelo et al., 2006; Von Eije \& Megginson, 2008; Chen et al., 2017), we exclude financial firms from the sample, as they are heavily regulated and thus might behave differently in terms of dividend policy. Our final unbalanced panel datasets consist of 3,365 observations on 525 non-financial listed firms in Indonesia.

\section{B. Methodology}

To examine the effect of board gender diversity on dividend policy, we use the following regressions as our baseline model.

$$
\begin{aligned}
& \operatorname{Div} / T A_{i, t}=\alpha_{i}+\beta_{1} F B C_{i, t}+\beta_{2} F B D_{i, t}+\sum_{k=1}^{7} \delta_{k} C k_{i, t}+\varepsilon_{i, t} \\
& \log \left(\frac{D D_{i v_{i, t}}}{1-D \operatorname{Div}_{i, t}}\right)=\alpha_{i}+\beta_{1} F B C_{i, t}+\beta_{2} F B D_{i, t}+\sum_{k=1}^{7} \delta_{k} C k_{i, t}+\varepsilon_{i, t}
\end{aligned}
$$

where Div/TA is the ratio of cash dividends to total assets (in percentage) for firm $i$ at time $t$, and $D D i v_{i, t}$ is a dummy for paying dividends at time $t . F B C_{i, t}$ and $F B D_{i, t}$ measure the female board commissioners and directors of firm $i$ at time $t$ respectively. $C k_{i, t}$ is control variables $k$ of firm $i$ at time $t$. These control variables are, among others, Ln TA, ROA, Growth TA, Leverage, DFamily, and Cash/TA. 
We define dividend policy in terms of both the amount of cash dividends and the propensity to pay dividends. Following Fama and French (2001), Dewasiri et al. (2019), and Ye et al. (2019), we use a dummy variable for the propensity to pay dividends, which takes a value of one if a firm pays dividends (DDiv) and zero otherwise. Following Francis et al. (2011), we also use the ratio of cash dividends scaled by total assets (Div/TA), rather than the ratio of dividends to earnings, to measure the amount of cash dividends paid. This approach avoids having a ratio of dividends to net income that exceeds one (or 100\%).

The main independent variable is female board members in a two-tiered board system, to measure gender diversity on the two types of board; that is, female members of the board of commissioners $(F B C)$ and female members of the board of director (FBD). Following Gul et al. (2011) and Ye et al. (2019), we use the number of female board members and the natural logarithm of the number of female board members plus one (Ln(number of female board members +1$)$ ), to avoid missing values if there is no female board member (zero). Following Chen et al. (2017), we also measure gender diversity as the proportion of female board members.

To avoid omitted variable bias, we include several control variables in our empirical model. First, following Fama and French (2001), we include firm size, measured by the logarithm of total assets $(\operatorname{Ln} T A),{ }^{2}$ profitability, measured by return on assets $(R O A)$, and firm growth, measured by the annual growth of total assets (Growth TA). Second, as the literature provides strong empirical evidence that dividend policy follows firms' life cycle (DeAngelo et al., 2006; Von Eije \& Megginson, 2008; Fatemi \& Bildik, 2012; Brawn \& Šević, 2018; Wardhana \& Tandelilin, 2018), we use firm age as a proxy for the firm life cycle. A third control added to the model is leverage ( $L E V)$, measured as the ratio of total debt to total assets, as creditors might limit the dividend payout in order to protect their interest in a firm (Cao et al., 2017; Lepetit et al., 2018). Fourth, we add ownership variables as abundant empirical studies show that it matters in dividend decisions (Grinstein \& Michaely, 2005; Bøhren et al., 2012; Lacave \& Urtiaga, 2015; Mulyani et al., 2016). We include this variable in the Indonesian context, in which family ownership is dominant (Grinstein \& Michaely, 2005; Bøhren et al., 2012; Lacave \& Urtiaga, 2015; Mulyani et al., 2016). So, the ownership variable (DFamily) is included in the model to indicate whether a family controls a firm. Last, following DeAngelo et al. (2006), we include cash on hand as a firm's ability to pay dividends can be observed directly with the level of cash on hand. To measure cash on hand, in this paper, we use the ratio of cash divided by total assets (Cash/TA).

The Equation (1) is estimated using the fixed-effects estimator. In Equation (2), in which the dependent variable is binary, we use a logit regression with random-effects and industry-fixed effects, following Von Eije and Megginson (2008) and Wardhana and Tandelilin (2018), to investigate the impact of gender diversity on the propensity to pay dividends. Regarding endogeneity issues of our main variable, we perform a Durbin-Wu-Hausman (DWH) (Durbin, 1954; Wu, 1973; Hausman, 1978) test to see whether $F B C$ and $F B D$ are endogenous. Following Chen et al. (2017), our first instrument is female participation to male

\footnotetext{
2 We use the growth of assets instead of the market-to-book value to avoid potential endogeneity issues between firm value and dividends as dividends affect firm value.
} 
participation. The higher the female participation to male ratio in the labor force, the higher the chance for a firm to get a good female candidate as a director or a commissioner (Chen et al., 2017). Therefore, the female participation to male ratio will have a positive correlation with the number or the proportion of female directors/commissioners. The data on labor participation is retrieved from the World Bank database. Another instrument we use in this paper is the lagged value of total boards. According to Anderson and Hsiao (1981), the lagged value of the instrumented variable is highly correlated with the instrumented variable but not with the error term at time. Therefore, the lag value of the instrumented variable is also a suitable instrument.

The DWH test shows a chi-squared of 1.533 with a $p$-value of 0.212 , indicating that the number of $F B C$ and $F B D$ is not endogenous. The instruments pass the weak instrument test with Kleibergen-Paap rk Wald F-statistics of 55.22 over 11.04 of the lowest Stock-Yogo critical value (11.04). The instruments are also valid, with a $p$-value from Hansen $J$-statistics of 0.212 . Therefore, we proceed with the estimations using fixed-effects and logit regression. ${ }^{3}$

\section{RESULTS}

\section{A. Descriptive Statistics}

Table 1 shows the descriptive statistics of all variables used in this study after winsorizing extreme values at 1 percent and 99 percent. ${ }^{4}$ Table 2 shows that Indonesian firms, on average, pay cash dividends of 1.5 percent of their total assets. Only 44 percent of the firms pay cash dividends over the sample period. This is less than in previous years, as shown by Wardhana and Tandelilin (2018), with seventeen years of observations ending in 2011, when 50 percent of the firms paid dividends. Therefore, the trend toward paying smaller dividends in Indonesia is consistent with patterns seen at firms around the world in recent empirical studies (Fatemi \& Bildik, 2012).

Regarding board gender diversity, Table 1 reports that 34 percent of the firms have female commissioners $(D F B C)$, and 53 percent of the firms have female board directors $(D F B D)$. Figure 1 shows the trends in the relevant variables over our sample period (i.e. from 2011 to 2018). The amount of cash dividend payments (ratio of cash dividends scaled by total assets) declined over the sample period, although it increased after 2016. The proportion of female board members rises over the sample period, indicating a negative association between cash dividends paid and female board members' proportion. To further investigate the causal relationship between women on board and dividend policy considering firm individual heterogeneity, we use regression estimations in the next section.

\footnotetext{
3 In the case of potential reverse causality, we argue that the firm's cash dividends do not influence female board members' number or proportion. We suspect that our female board variable is not endogenous in this case. Yet, we take more precaution by testing the presence of endogeneity.

4 For variable leverage ( $L E V)$, we reduce values larger than 100 .
} 
Table 1.

Descriptive Statistics of Variables, 2011-2018

This table has descriptive statistics. Div/TA = Dividend*100/Total Assets. DDiv is a dummy that equals to one if the firm pays dividends. $F B C$ is the number of female members of the board of commissioners $(B o C), F B D$ is the number of female members of the board of directors (BoD). $F B C(\%)$ and $F B D(\%)$ is the proportion of females on the BoC and BoD, respectively. $D F B C$ and $D F B D$ is dummy variable that equals one if there is female member of the BoC and $\mathrm{BoD}$, respectively. $R O A$ is Net income* $100 /$ Total assets. $L E V$ is Debt ${ }^{*} 100 /$ Total assets. DFamily is a dummy variable that takes a value of one if the firm is controlled by a family, where one or more $\mathrm{BoC}$ or $\mathrm{BoD}$ members come from the same family whose aggregate ownership is more than $10 \%$. Age is firm age. TA is total assets. Cash/TA computed as Cash*100/Total assets. Growth TA is yearly growth of assets in percent.

\begin{tabular}{lccccc}
\hline Variable & Obs. & Mean & Std. Dev. & Min. & Max. \\
\hline Div/TA & 3,365 & 1.550 & 3.932 & 0 & 25.661 \\
DDiv & 3,365 & 0.447 & 0.497 & 0 & 1 \\
FBC & 3,365 & 0.437 & 0.718 & 0 & 6 \\
FBD & 3,365 & 0.583 & 0.855 & 0 & 8 \\
FBC $(\%)$ & 3,360 & 11.332 & 18.512 & 0 & 100 \\
FBD $(\%)$ & 3,363 & 12.792 & 18.093 & 0 & 100 \\
DFBC & 3,365 & 0.338 & 0.473 & 0 & 1 \\
DFBD & 3,365 & 0.412 & 0.492 & 0 & 1 \\
ROA & 3,365 & 3.084 & 11.501 & -51.234 & 39.727 \\
LEV & 3,365 & 48.957 & 23.778 & 2.44 & 99.73 \\
DFamily & 3,365 & 0.290 & 0.454 & 0 & 1 \\
Age & 3,365 & 30.053 & 16.709 & 1 & 113 \\
Total assets (million USD) & 3,365 & 629,860 & $1,507,212$ & 159 & $23,800,000$ \\
Cash/TA & 3,365 & 9.388 & 10.358 & 0.055 & 52.265 \\
Growth TA & 3,365 & 14.174 & 61.604 & -48.635 & 541.491 \\
\hline
\end{tabular}

\section{Trends in Female Board of Commissioners, Directors, and Cash Dividends (2011-2018)}

This figure shows the trend in female board of commissioners, directors, and cash dividends over the period from 2011 to 2018. FBC and FBD denote, respectively, the proportion of female board commissioners and directors, while Div/TA is cash dividends scaled by total assets.

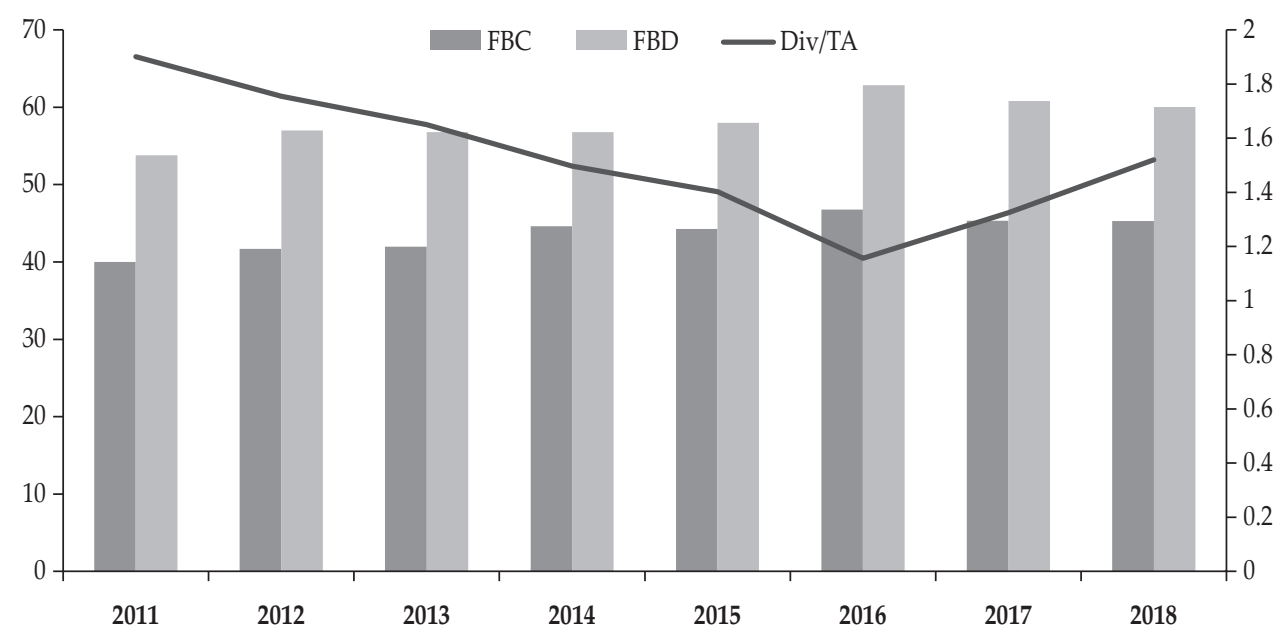




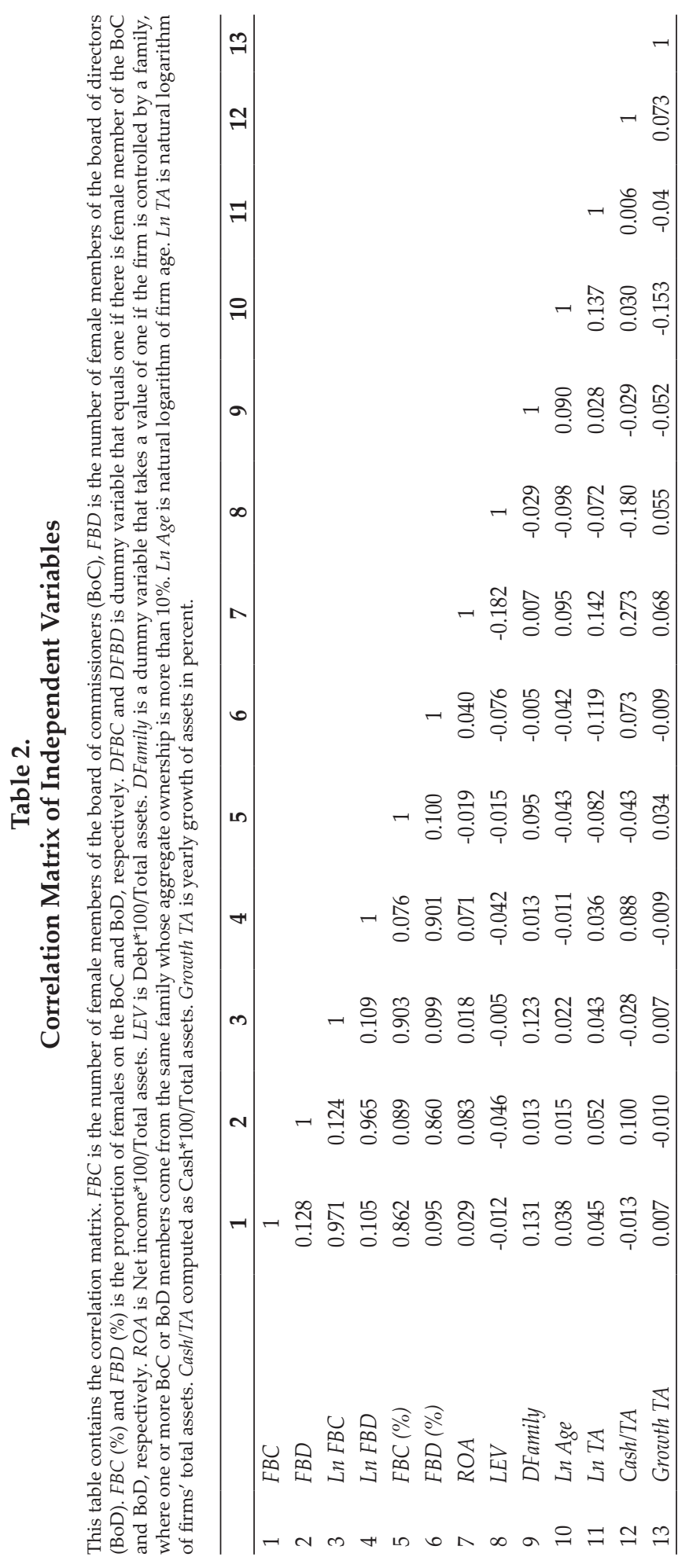


We also provide a matrix of correlation in Table 2 to show the absence of potential multicollinearity issues among the independent variables.

\section{B. Baseline Result}

Table 3 presents our baseline results. In columns 1 and 2, we use the number of female board members and its log value, respectively, while in column 3 we use the proportion of female members of each board. We use a fixed-effects estimator for the cash dividend estimation to address individual fixed effects. The Hausman test shows that the fixed-effects model is best for our data. We use a panel data logit regression alongside a random-effects regression for the propensity to pay dividends, following Von Eije and Megginson (2008). To minimize individual effects, we include industry-fixed effects in our logit regression.

\section{Table 3.}

\section{Baseline: Fixed Effects Regression Female Board Members on Dividends, 2011-2018}

This table has fixed-effects regression results. The dependent variable is Div/TA $=$ Cash dividends*100/Total assets. $F B C$ is the number of female members of the board of commissioners $(\mathrm{BoC}), F B D$ is the number of female members of the board of directors $(\mathrm{BoD}) . F B C(\%)$ and $F B D(\%)$ is the proportion of females on the $\mathrm{BoC}$ and $\mathrm{BoD}$, respectively. $L n$ $F B C$ and $L n F B D$ is natural logarithm of $F B C$ and $F B D$, respectively. ROA is Net income*100/Total assets. L.LEV is lag of Debt*100/Total assets. DFamily is a dummy variable that takes a value of one if the firm is controlled by a family, where one or more BoC or BoD members come from the same family whose aggregate ownership is more than $10 \%$. Ln Age is the natural logarithm of firm age. Ln TA is natural logarithm of the firms' total assets. Cash/TA computed as Cash $^{*} 100 /$ Total assets. Growth TA is yearly growth of assets in percent. Robust standard error clustered by firm are in parentheses. Finally, ${ }^{*} p<0.10,{ }^{* * *} p<0.05,{ }^{* * * *} p<0.01$.

\begin{tabular}{|c|c|c|c|}
\hline Div/TA & (1) & (2) & (3) \\
\hline$F B C$ & $\begin{array}{c}0.0527 \\
(0.0919)\end{array}$ & & \\
\hline$F B D$ & $\begin{array}{l}-0.270^{* *} \\
(0.122)\end{array}$ & & \\
\hline Ln FBC & & $\begin{array}{c}0.150 \\
(0.168)\end{array}$ & \\
\hline Ln FBD & & $\begin{array}{l}-0.498^{* *} \\
(0.247)\end{array}$ & \\
\hline$F B C(\%)$ & & & $\begin{array}{c}0.00328 \\
(0.00379)\end{array}$ \\
\hline$F B D(\%)$ & & & $\begin{array}{c}-0.00903 \\
(0.00568)\end{array}$ \\
\hline$R O A$ & $\begin{array}{c}0.0405^{* * * *} \\
(0.00813)\end{array}$ & $\begin{array}{c}0.0405^{* * *} \\
(0.00813)\end{array}$ & $\begin{array}{c}0.0403^{2 \ldots+x} \\
(0.00809)\end{array}$ \\
\hline L.LEV & $\begin{array}{l}-0.0172+ \\
(0.00482)\end{array}$ & $\begin{array}{l}-0.0172 \\
(0.00483)\end{array}$ & $\begin{array}{l}-0.0164^{*+*+} \\
(0.00458)\end{array}$ \\
\hline DFamily & $\begin{array}{l}-0.725^{* *} \\
(0.335)\end{array}$ & $\begin{array}{l}-0.720^{* *} \\
(0.333)\end{array}$ & $\begin{array}{l}-0.725^{*} \\
(0.332)\end{array}$ \\
\hline Ln Age & $\begin{array}{l}1.435^{* *} \\
(0.679)\end{array}$ & $\begin{array}{l}1.449^{* * *} \\
(0.680)\end{array}$ & $\begin{array}{l}1.463^{* *} \\
(0.678)\end{array}$ \\
\hline $\operatorname{Ln} T A$ & $\begin{array}{c}-0.156^{*} \\
(0.0936)\end{array}$ & $\begin{array}{c}-0.158^{*} \\
(0.0935)\end{array}$ & $\begin{array}{l}-0.160^{*} \\
(0.0926)\end{array}$ \\
\hline Cash/TA & $\begin{array}{c}0.0130 \\
(0.0109) \\
\end{array}$ & $\begin{array}{c}0.0130 \\
(0.0109) \\
\end{array}$ & $\begin{array}{c}0.0127 \\
(0.0109)\end{array}$ \\
\hline
\end{tabular}


Table 3.

Baseline: Fixed Effects Regression Female Board Members on Dividends, 2011-2018 (Continued)

\begin{tabular}{lccc}
\hline Div/TA & $\mathbf{( 1 )}$ & $\mathbf{( 2 )}$ & $\mathbf{( 3 )}$ \\
\hline \multirow{2}{*}{ Growth TA } & $-0.00150^{* * *}$ & $-0.00151^{* *}$ & $-0.00157^{* *}$ \\
& $(0.000726)$ & $(0.000726)$ & $(0.000726)$ \\
Cons & 0.209 & 0.201 & 0.0833 \\
& $(2.297)$ & $(2.298)$ & $(2.286)$ \\
\hline Year FE & Yes & Yes & Yes \\
No. of obs. & 3365 & 3365 & 3358 \\
No. of groups & 525 & 525 & 524 \\
R-Squared Within & 0.0562 & 0.0563 & 0.0551 \\
F-stat & $3.573^{* * *}$ & $3.651^{* * *}$ & $3.509^{* * *}$ \\
\hline
\end{tabular}

The main message from Table 3 is that female commissioners $(F B C)$ do not seem to be related to the amount of cash dividend payments. These results are consistent, whether we use the number of females on the board ( $F B D$ or $F B C$ ) or its $\log$ value ( $L n F B D$ or $L n F B C$ ). However, the number of female directors $(F B D)$ is negatively related to cash dividend payments, implying that a higher number of women directors tend to decrease dividend payments. Meanwhile, the coefficient for the proportion of female board members (FBD (\%) or FBC (\%)) is not statistically significant. We assume that this is due to the tiny within variation of the proportion of female board members variable. We compute the mean of the within variance of both the proportion of $F B C$ and $F B D$ and find the value is nearly zero. Overall, at this point, our baseline estimates show that a higher number of female members on the executive board tends to decrease cash dividend payments and that $F B D$ has a more significant role in dividend policy decisions than $F B C$. These findings do not support our first hypothesis that in a country with weak investor protection, a high dividend payment mitigates agency conflicts, and thus female board members, who pay greater attention to shareholder interests, tend to encourage higher dividend payments.

However, the finding on the relationship between FBD and dividend payments, overall, supports our second hypothesis that female directors have a negative effect on dividend payment. In column 1 of Table 3, we observe that one additional female director is associated with a decline in dividends scaled by total assets (Div/TA) by $0.27 \%$. This decline is relatively significant, since the sample mean of Div/TA is $1.55 \%$, with a standard deviation of $3.93 \%$. Empirical studies find that female directors are not as overconfident as male directors when making corporate decisions (Huang \& Kisgen, 2013) and are less risk-tolerant than male board members (Levi et al., 2014). In this case, female directors prefer to hold on to more cash, hence, paying smaller cash dividends for a precautionary motive. This result supports Saeed and Sameer (2017) findings that, in an emerging country, female directors have a precautionary motive in lowering cash dividend distribution to retain more cash on hand as a buffer for rainy days in the future. This argument is appropriate in an emerging country with high business risk, a more volatile stock market, and high inflation, such as Indonesia. 
The effect of female board members on a firm's propensity to pay dividends is reported in Table 4 . We find no evidence that female board members, whether FBC or $F B D$, influence the tendency to pay dividends.

Table 4.

Baseline: Random-Effects Logit Regression Female Board Members on Dividends, 2011-2018

This table has random effects logit regression results with industry-fixed effects. The dependent variable is DDiv or a dummy variable that equals to one if the firm pays dividends. $F B C$ is the number of female members of the board of commissioners $(\mathrm{BoC}), F B D$ is the number of female members of the board of directors $(\mathrm{BoD}) . F B C(\%)$ and $F B D(\%)$ is the proportion of females on the BoC and BoD, respectively. $L n F B C$ and $L n F B D$ is natural logarithm of $F B C$ and FBD, respectively. ROA is Net income*100/Total assets. L.LEV is lag of Debt*100/Total assets. DFamily is a dummy variable that takes a value of one if the firm is controlled by a family, where one or more $\mathrm{BoC}$ or BoD members come from the same family whose aggregate ownership is more than $10 \%$. Ln Age is the natural logarithm of firm age. Ln $T A$ is natural logarithm of the firms' total assets. Cash/TA computed as Cash*100/Total assets. Growth TA is yearly growth of assets in percent. Standard error in parentheses, with observed information matrix standard error. Finally, " $p<0.10,{ }^{* *} p<0.05,{ }^{* * *} p<0.01$.

\begin{tabular}{|c|c|c|c|}
\hline DDiv & (1) & (2) & (3) \\
\hline Ln FBC & $\begin{array}{l}0.314^{*} \\
(0.162)\end{array}$ & & \\
\hline Ln FBD & $\begin{array}{c}0.130 \\
(0.136)\end{array}$ & & \\
\hline$F B C(\%)$ & & $\begin{array}{c}0.393 \\
(0.281)\end{array}$ & \\
\hline$F B D(\%)$ & & $\begin{array}{c}0.298 \\
(0.255)\end{array}$ & \\
\hline$D F B C$ & & & $\begin{array}{c}0.00630 \\
(0.00636)\end{array}$ \\
\hline$D F B D$ & & & $\begin{array}{c}0.00976 \\
(0.00619)\end{array}$ \\
\hline$R O A$ & $\begin{array}{l}0.0930^{*+4} \\
(0.0117)\end{array}$ & $\begin{array}{l}0.0933^{*+* * *} \\
(0.0117)\end{array}$ & $\begin{array}{l}0.0930^{*+* 4+} \\
(0.0117)\end{array}$ \\
\hline L.LEV & $\begin{array}{l}-0.0349^{*} \\
(0.00578)\end{array}$ & $\begin{array}{l}-0.0349^{* * *} \\
(0.00578)\end{array}$ & $\begin{array}{l}-0.0350^{*} \\
(0.00580)\end{array}$ \\
\hline DFamily & $\begin{array}{c}0.253 \\
(0.326)\end{array}$ & $\begin{array}{c}0.265 \\
(0.326)\end{array}$ & $\begin{array}{c}0.252 \\
(0.327)\end{array}$ \\
\hline Ln Age & $\begin{array}{l}0.963^{*} \\
(0.274)\end{array}$ & $\begin{array}{l}0.968 \\
(0.273)\end{array}$ & $\begin{array}{l}1.003^{* * *} \\
(0.275)\end{array}$ \\
\hline $\operatorname{Ln} T A$ & $\begin{array}{l}1.250^{* * *+} \\
(0.119)\end{array}$ & $\begin{array}{l}1.251^{*} \\
(0.119)\end{array}$ & $\begin{array}{l}1.287^{* 0 *} \\
(0.120)\end{array}$ \\
\hline Cash/TA & $\begin{array}{l}0.0421^{*+1} \\
(0.0113)\end{array}$ & $\begin{array}{l}0.0417^{\text {ant }} \\
(0.0113)\end{array}$ & $\begin{array}{l}0.0415^{*+3+} \\
(0.0113)\end{array}$ \\
\hline Growth TA & $\begin{array}{l}-0.00593^{*+1} \\
(0.00194)\end{array}$ & $\begin{array}{c}-0.00599^{0+4} \\
(0.00194)\end{array}$ & $\begin{array}{c}-0.00583^{*+*+} \\
(0.00194)\end{array}$ \\
\hline Cons & $\begin{array}{l}-16.51^{* n+4} \\
(1.876)\end{array}$ & $\begin{array}{l}-16.54^{\text {san }} \\
(1.874)\end{array}$ & $\begin{array}{l}-17.05^{*+4} \\
(1.902)\end{array}$ \\
\hline Industry FE & Yes & Yes & Yes \\
\hline No. of obs. & 3365 & 3365 & 3358 \\
\hline No. of groups & 525 & 525 & 524 \\
\hline Log likelihood & -1181.7 & -1182.3 & -1180.3 \\
\hline
\end{tabular}


In the baseline results in Table 3, the control variables support the previous findings, hence, supporting the dividend life-cycle hypothesis, as in Wardhana and Tandelilin (2018). We find that firm age and profitability have a positive relationship with dividend payments, whereas growth has a negative one. As for the propensity to pay dividends, reported in Table 4, we also find that firm age, profitability, and size positively affect the propensity to pay dividends, but growth has a negative impact. Our other finding suggests that leverage has a negative impact on both cash dividends and the propensity to pay them, supporting Jensen (1986). In contrast, family-owned firms tend to pay lower dividends and have a lower propensity to pay dividends, which confirms existing empirical evidence such as Bøhren et al. (2012) and Mulyani et al. (2016).

\section{Further Analysis}

Motivated by the predominance of Indonesian family-controlled firms, we investigate whether family-controlled firms, which typically appoint family members as board members to ensure their interest in the firms (Yoshikawa \& Rasheed, 2010), influence the relationship between female board members and dividend policy decisions. Another distinct characteristic of Asian listed firms is concentrated ownership and a pyramidal ownership structure (Faccio et al., 2001), which lead to expropriation by minority shareholders. In Indonesia, familycontrolled businesses as well as a pyramidal ownership structure are also dominant (Claessens et al., 1999), and family-controlled firms' market capitalization accounts for about 40 percent of the Indonesian capital market (Mulyani et al., 2016). Our sample shows that 30 percent of the non-financial firms are family-run businesses. Hence, we further investigate the role of $F B C$ and $F B D$ in dividend policy in family businesses. We do this by introducing the interaction variables $F B C^{*} F a m i l y$ and $F B D^{*}$ Family in the regressions and report the results in Tables 5 and 6 for cash dividends and the propensity to pay them, respectively.

Table 5.

\section{Interaction: Fixed-Effects Regression Female Board Members on Dividends by} Family Ownership, 2011-2018

This table has fixed-effects regression results. The dependent variable is Div/TA $=$ Cash dividends $100 /$ Total assets. $L n F B C$ is the natural logarithm of the number of female members of the board of commissioners (BoC) and $L n F B D$ is natural logarithm of the number of female members of the board of directors $(\mathrm{BoD}) . F B C(\%)$ and $F B D(\%)$ is the proportion of females on the $\mathrm{BoC}$ and $\mathrm{BoD}$, respectively. $D F B C$ and $D F B D$ is dummy variables of $F B C$ and $F B D$, respectively. DFamily is a dummy variable that equals one if firm is controlled by a family. Robust standard errors clustered by the firms are in parentheses. Finally, ${ }^{*} p<0.10,{ }^{* *} p<0.05,{ }^{* * *} p<0.01$.

\begin{tabular}{lccc}
\hline & $\mathbf{( 1 )}$ & $\mathbf{( 2 )}$ & $\mathbf{( 3 )}$ \\
\hline \multirow{2}{*}{$F B C$} & Ln FBC or $\operatorname{Ln}$ FBD & FBC $\mathbf{( \% )}$ or FBD $\mathbf{( \% )}$ & DFBC or DFBD \\
\multirow{2}{*}{ FBC* Family } & 0.190 & $0.368^{*}$ & 0.00719 \\
& $(0.118)$ & $(0.212)$ & $(0.00504)$ \\
FBD & $-0.439^{* *}$ & $-0.766^{* *}$ & -0.0172 \\
& $(0.205)$ & $(0.349)$ & $(0.0106)$ \\
FBD*Family & $-0.365^{* *}$ & $-0.729^{* *}$ & $-0.0130^{*}$ \\
& $(0.149)$ & $(0.298)$ & $(0.00703)$ \\
& $0.338^{*}$ & $0.901^{* *}$ & $0.0177^{* *}$ \\
& $(0.203)$ & $(0.380)$ & $(0.00847)$ \\
\hline
\end{tabular}


Table 5.

Interaction: Fixed-Effects Regression Female Board Members on Dividends by Family Ownership, 2011-2018 (Continued)

\begin{tabular}{lccc}
\hline & $\mathbf{( 1 )}$ & $\mathbf{( 2 )}$ & $\mathbf{( 3 )}$ \\
\hline Year FE & Ln FBC or $\boldsymbol{L n}$ FBD & FBC $\mathbf{( \% )}$ or $\boldsymbol{F B D} \mathbf{( \% )}$ & DFBC or DFBD \\
Controls & Yes & Yes & Yes \\
No. of obs. & Yes & Yes & Yes \\
No. of groups & 3365 & 3365 & 3358 \\
R-Squared Within & 525 & 525 & 524 \\
F-stat & 0.0588 & 0.0600 & 0.0579 \\
\hline
\end{tabular}

Table 6.

Interaction: Random-Effects Logit Regression Female Board Members on Dividends by Family, 2011-2018

This table has random-effects logit regression results with industry-fixed effects. The dependent variable is DDiv or a dummy variable that equals to one if the firm pays dividends. $L n F B C$ is the natural logarithm of the number of female members of the board of commissioners (BoC) and $L n F B D$ is natural logarithm of the number of female members of the board of directors (BoD). $F B C(\%)$ and $F B D(\%)$ is the proportion of females on the BoC and BoD, respectively. $D F B C$ and $D F B D$ is dummy variables of $F B C$ and $F B D$, respectively. DFamily is a dummy variable that equals one if firm is controlled by a family. $z$ statistics are in parentheses, with observed information matrix standard error. Finally, ${ }^{*} p<0.10,{ }^{* *} p<0.05,{ }^{* * *} p<0.01$.

\begin{tabular}{lccc}
\hline & $\mathbf{( 1 )}$ & $\mathbf{( 2 )}$ & $\mathbf{( 3 )}$ \\
\hline FBC & Ln FBC or $\operatorname{Ln}$ FBD & FBC (\%) or FBD (\%) & DFBC or DFBD \\
\hline \multirow{2}{*}{ FBC Family } & $0.497^{* * *}$ & $0.718^{* *}$ & $0.0133^{*}$ \\
& $(2.55)$ & $(2.16)$ & $(1.84)$ \\
FBD & $-0.573^{*}$ & $-1.134^{* *}$ & $-0.0266^{* *}$ \\
& $(-1.81)$ & $(-1.99)$ & $(-2.09)$ \\
FBD*Family & 0.0150 & 0.0313 & 0.00715 \\
& $(0.09)$ & $(0.10)$ & $(0.99)$ \\
Industry FE & 0.444 & $1.012^{*}$ & 0.0120 \\
Controls & $(1.51)$ & $(1.88)$ & $(0.91)$ \\
No. of obs. & Yes & Yes & Yes \\
No. of groups & Yes & Yes & Yes \\
Log likelihood & 3365 & 3365 & 3358 \\
\hline
\end{tabular}

In Table 5, $F B C^{*}$ Family is statistically significant with a negative sign for the number of female board members (see columns (1) and (2)), but $F B C$ is not statistically significant. This indicates that a higher $F B C$ is associated with a lower cash dividend payment at family firms, but not at non-family-controlled firms. This finding shows that female commissioners are actively involved in cash dividend decisions at family-controlled firms, indicating that female commissioners prefer to have more buffers to ensure the long-term sustainability of family-controlled businesses (Prencipe et al., 2011). 
We find that the main effect, $F B D$, is negative and statistically significant at the 5 percent level, especially for the number of $F B D$. Yet, FBD*Family appears to be positive and significant, indicating that female directors are also involved in cash dividend decisions at family-controlled firms. We then perform a Wald test to evaluate the coefficient of the interaction term. The coefficient of FBD at non-family-controlled firms is -0.729 , indicating a negative effect of $F B D$ on cash dividend payouts, while for $F B D$ at family-controlled firms, it is $0.172(-0.729+$ $0.901)^{5}$ but not statistically significant. This result indicates that $F B D$ has a negative association with cash dividend payments only in the non-family-controlled firms.

Table 6 shows the result for the propensity to pay dividends. The main effect for $F B C$ is positive and significant for the number of $F B C$ (columns 2 and 3), whereas the interaction term $F B C^{*} F a m i l y$ is negative and significant. This means we observe different $F B C$ effects on the propensity to pay dividends between the two groups. We perform a Wald test in column 2 to see whether the impact of $F B C$ on family-controlled firms is significant; we find a coefficient of $-0.416(0.718-1.134)^{6}$. However, this coefficient is not statistically significant, leading us to conclude that female commissioners are involved in decisions to pay dividends at non-familycontrolled firms but not family-controlled firms. This result indicates that female commissioners act on behalf of the minority shareholders by promoting dividend payments to reduce agency conflicts between the majority and the minority shareholders. This finding supports our first hypothesis, but only for non-familycontrolled firms. However, we do not find a significant coefficient in the main effect and the interaction terms when considering FBD in our regression, so the baseline result stands that $F B D$ does not impact the propensity to pay dividends.

\section{Robustness Checks}

We perform a series of robustness tests to see whether our results are altered. To save space, all the robustness checks are not shown. First, we estimate Equation (1) using the Tobit regression estimator following the study of Francis et al. (2011), Al-Malkawi et al. (2014), Jiang et al. (2019), and Driver et al. (2020), which consider that dividend payout are left-censored at zero. We find the results unchanged. We also estimate Equation (2) using a Probit regression estimator with random and industry fixed effects for robustness and document similar results.

In our sample, the number of firms with female board members is relatively smaller compared to firms without female board members. The proportion of firms with FBD in the sample is 33\% while the proportion of firms with FBC is $41 \%$. Therefore, we also use propensity score matching to have matching firms to compare between the two groups (with vs. without female board members). We use a logit regression to compute the propensity score. We use the model $D F C=f($ number of total directors, $R O A$, lagged leverage, firm size, family firm dummy, growth, and industry-fixed effects) and $D F B=f$ (number of total directors,

\footnotetext{
5 To obtain the coefficient of variable FBD for family controlled firms, we add the coefficient of FBD with the coefficient of FBD*Family, $-0.729+0.901=0.172$.

6 To obtain the coefficient of variable FBC for family controlled firms, we add the coefficient of FBD with the coefficient of FBD*Family, $0.718-1.134=0.416$.
} 
$R O A$, lagged leverage, firm size, family firm dummy, growth, and industry-fixed effects). DFC is a dummy variable that takes value of one if a firm has female board of commissioner and zero otherwise while DFB is a dummy variable that takes value of one if a firm has female board of director and zero otherwise. The results for cash dividends and the propensity to pay dividends remain unchanged.

We also run the estimations by excluding firms that pay no dividends as well as test whether our results change by excluding utility firms because they are heavily regulated as financial firms ${ }^{7}$. Again, our conclusions remain the same. We also consider the initial level of dividend, which could explain firms' dividend policies. ${ }^{8}$ Firms that pay dividend in the past are more likely to pay dividends in the future. We estimate Equation (2) with the initial dividend and we obtain similar results as in the baseline.

\section{CONCLUSION}

This article examines the role of diversity, in terms of female board members, on the dividend payment policy of listed firms in Indonesia, which has a twotiered board system. This governance system consists of two distinct layers: nonexecutives on the board of commissioners and executives on the board of directors. The former is tasked with monitoring, while the latter ensures that firm decisions and policies aimed at increasing shareholder wealth. Using various regression approaches and control variables, we find that the presence of females on the board of commissioners influence corporate dividend decisions. The involvement of female commissioners is more notable in family-controlled firms, as they prevent higher dividend distribution and thereby retain more cash as a buffer to ensure business sustainability in these firms. We find a negative association between female board of directors and dividend payments in both family-controlled and non-family-controlled firms, indicating risk-aversion and precautionary behavior of female directors. Nevertheless, female commissioners' involvement in cash dividend decisions appear only at non-family-controlled firms and only in the amount of cash dividend payments, with a negative relationship. Further investigation shows that the propensity to pay dividends is more determined by female commissioners, with a positive influence, and in non-family-controlled business only. We also conduct several robustness tests using a Tobit regression, a probit regression, as well as propensity score matching, and we arrive at the same conclusions.

This study offers the insight that female board members in the two-tiered Indonesian system might actively be involved in firms' strategic decisions such as the decision to pay or not to pay dividends. Using a sample of listed nonfinancial firms in Indonesia, we find a shred of evidence indicating that both female commissioners and directors influence dividend policies but with different roles and behavior that are contingent on firm ownership, i.e., family-controlled vs. non-family-controlled firms. Future research should consider whether female commissioners' decisions at family-controlled firms to retain more earnings

\footnotetext{
7 We thank an anonymous referee for suggesting this.

8 This was also suggested by an anonymous referee.
} 
are aligned with the interest of minority shareholders or whether the low cash dividends result from better monitoring by female commissioners, which sends a positive signal to minority shareholders.

\section{REFERENCES}

Adams, R.B. (2016). Women on Boards: The Superheroes of Tomorrow? The Leadership Quarterly, 27, 371-386.

Adams, R.B., \& Ferreira, D. (2009). Women in the Boardroom and Their Impact on Governance and Performance. Journal of Financial Economics, 94, 291-309.

Adams, R.B., \& Funk, P. (2012). Beyond the Glass Ceiling: Does Gender Matter? Management Science, 58, 219-235.

AIPEG, (2017). Women's Economic Participation in Indonesia. Australia Indonesia Partnership for Economic Governance.

Al-Malkawi, H.-A.N., Bhatti, M.I., \& Magableh, S.I. (2014). On the Dividend Smoothing, Signaling and The Global Financial Crisis. Economic Modelling, 42, 159-165.

Amore, M.D., Garofalo, O., \& Minichilli, A. (2014). Gender Interactions Within the Family Firm. Management Science, 60, 1083-1097.

Anderson, T., \& Hsiao, C. (1981). Estimation of Dynamic Models with Error Components. Journal of American Statistical Association, 76, 598-606.

Baixauli-Soler, J.S., Belda-Ruiz, M., \& Sanchez-Marin, G. (2015). Executive Stock Options, Gender Diversity in the Top Management Team, and Firm Risk Taking. Journal of Business Research, 68, 451-463.

Balachandran, B., Khan, A., Mather, P., \& Theobald, M., (2019). Insider Ownership And Dividend Policy in An Imputation Tax Environment. Journal of Corporate Finance, 54, 153-167.

Benjamin, S.J., \& Biswas, P. (2019). Board Gender Composition, Dividend Policy and COD: The Implications of CEO Duality. Accounting Research Journal, 32, 454-476.

Bernardi, R.A., \& Arnold, D.F., (1997). An Examination of Moral Development within Public Accounting by Gender, Staff Level, and Firm*. Contemporary Accounting Research. 14, 653-668.

Bernile, G., Bhagwat, V., \& Yonker, S. (2018). Board Diversity, Firm Risk, and Corporate Policies. Journal of Financial Economics, 127, 588-612.

Bøhren, Ø., Josefsen, M.G., \& Steen, P.E. (2012). Stakeholder Conflicts and Dividend Policy. Journal of Banking \& Finance, 36, 2852-2864.

Brawn, D.A., \& Šević, A. (2018). Firm Size Matters: Industry Sector, Firm Age and Volatility Do Too in Determining Which Publicly-Listed US Firms Pay A Dividend. International Review of Financial Analysis, 58, 132-152.

Brockman, P., \& Unlu, E. (2009). Dividend Policy, Creditor Rights, and the Agency Costs of Debt. Journal of Financial Economics, 92, 276-299.

Byoun, S., Chang, K., \& Kim, Y.S. (2016). Does Corporate Board Diversity Affect Corporate Payout Policy? Asia-Pacific Journal of Financial Studies, 45, 48-101.

Cao, L., Du, Y., Hansen, J.Ø. (2017). Foreign Institutional Investors and Dividend Policy: Evidence from China. International Business Review, 26, 816-827. 
Chen, J., Leung, W.S., \& Goergen, M. (2017). The Impact of Board Gender Composition on Dividend Payouts. Journal of Corporate Finance, 43, 86-105.

Cho, Y., Park, J., Han, S.J., \& Ho, Y. (2019). A Woman CEO? You'd Better Think Twice!: Exploring Career Challenges of Women CEOs At Multinational Corporations in South Korea. Career Development International, 24.

Claessens, S., Djankov, S., \& Lang, L.H.P. (2000). The Separation of Ownership and Control in East Asian Corporations. Journal of Financial Economics, 58, 81-112.

Claessens, S., Fan, J.P.H., Djankov, S., \& Lang, L.H.P. (1999). On Expropriation of Minority Shareholders: Evidence from East Asia. SSRN. Available at SSRN: http://ssrn.com/abstract=202390.

Cumming, D., Leung, T.Y., \& Rui, O. (2015). Gender Diversity and Securities Fraud. Academy of Management Journal, 58, 1572-1593.

Darmadi, S. (2010). Do Women in Top Management Affect Firm Performance? Evidence from Indonesia. Munich Personal RePEc Archive.

Darmadi, S. (2011). Board diversity and firm performance: The Indonesian evidence. Corporate Ownership and Control, 8, 450-466.

DeAngelo, H., DeAngelo, L., \& Stulz, R. (2006). Dividend Policy and the Earned/ Contributed Capital Mix: A Test of the Life-Cycle Theory. Journal of Financial Economics, 81, 227-254.

Deng, X. (2015). Father-daughter Succession in China: Facilitators and Challenges. Journal of Family Business Management, 5.

Dewasiri, N.J., Yatiwelle Koralalage Weerakoon, B., Abdul Azeez, A., Jayarathne, P.G.S.A., Kuruppuarachchi, D., \& Weerasinghe, V.A. (2019). Determinants of Dividend Policy: Evidence from An Emerging and Developing Market. Managerial Finance, 45, 413-429.

Driver, C., Grosman, A., \& Scaramozzino, P. (2020). Dividend Policy and Investor Pressure. Economic Modelling, 89, 559-576.

Durbin, J. (1954). Errors in Variable. Review of the International Statistical Institute, 22, 23-32.

Easterbrook, F.H. (1984). Two Agency-Cost Explanations of Dividends. The American Economic Review, 74, 650-659.

Faccio, M., Lang, L.H.P., \& Young, L. (2001). Dividends and Expropriation. The American Economic Review, 91, 54-78.

Fama, E.F., \& French, K.R. (2001). Disappearing Dividends: Changing Firm Characteristics or Lower Propensity to Pay? Journal of Financial Economics, 60, 3-43.

Fatemi, A., \& Bildik, R. (2012). Yes, Dividends are Disappearing: Worldwide Evidence. Journal of Banking \& Finance, 36, 662-677.

Francis, B.B., Hasan, I., John, K., \& Song, L. (2011). Payout Policy: A Test Using Antitakeover Legislation. Financial Management, 83-112.

Grinstein, Y., \& Michaely, R. (2005). Institutional Holdings and Payout Policy. The Journal of Finance, 60, 1389-1426.

Gul, F.A., Srinidhi, B., \& Ng, A.C. (2011). Does Board Gender Diversity Improve The Informativeness of Stock Prices? Journal of Accounting and Economics, 51, 314-338.

Hausman, J.A. (1978). Specification Tests in Econometrics. Econometrica, 46, 12511271. 
Huang, J., \& Kisgen, D.J., (2013). Gender and Corporate Finance: Are Male Executives Overconfident Relative to Female Executives? Journal of Financial Economics, 108, 822-839.

Indonesia, G.o. (2011). Gender Equality. Ministry of National Development Planning and Ministry of Women Empowerment and Child Protection Policy Brief.

Jensen, M.C. (1986). Agency Cost of Free Cash Flow, Corporate Finance, and Takeovers. American Economic Review, 76, 323-329.

Jianakoplos, N.A., \& Bernasek, A., (1998). Are Women More Risk Averse? Economic Inquiry, 36, 620-630.

Jiang, F., Cai, X., Jiang, Z., \& Nofsinger, J.R. (2019). Multiple Large Shareholders and Dividends: Evidence from China. Pacific-Basin Finance Journal, 57, 101201

Kang, E., Ding, D.K., \& Charoenwong, C. (2010). Investor Reaction to Women Directors. Journal of Business Research, 63, 888-894.

La Porta, R., Lopez-de-Silanes, F., Shleifer, A., \& Vishny, R.W. (2000). Agency Problems and Dividend Policies around the World. The Journal of Finance, 55, 1-33.

Lacave, M.S., \& Urtiaga, M.G. (2015). Dividend Policy with Controlling Shareholders. Theoretical Inquiries in Law 16, 107-130.

Lepetit, L., Meslier, C., Strobel, F., \& Wardhana, L. (2018). Bank Dividends, Agency Costs and Shareholder and Creditor Rights. International Review of Financial Analysis, 56, 93-111.

Levi, M., Li, K., \& Zhang, F. (20140. Director Gender and Mergers and Acquisitions. Journal of Corporate Finance, 28, 185-200.

Liu, C. (2018). Are Women Greener? Corporate Gender Diversity and Environmental Violations. Journal of Corporate Finance, 52, 118-142.

Mulyani, E., Singh, H., \& Mishra, S. (2016). Dividends, Leverage, and Family Ownership in The Emerging Indonesian Market. Journal of International Financial Markets, Institutions and Money, 43, 16-29

Ngo, A., Duong, H., Nguyen, T., \& Nguyen, L. (2018). The Effects of Ownership Structure on Dividend Policy: Evidence from Seasoned Equity Offerings (SEOs). Global Finance Journal, 100440.

Prencipe, A., Bar-Yosef, S., Mazzola, P., \& Pozza, L. (2011). Income Smoothing in Family-Controlled Companies: Evidence from Italy. Corporate Governance: An International Review, 19, 529-546.

Price, C.R. (2012). Gender, Competition, and Managerial Decisions. Management Science, 58, 114-122.

Pucheta-Martínez, M.C., \& Bel-Oms, I. (2015). The Board of Directors and Dividend Policy: The Effect of Gender Diversity. Industrial and Corporate Change, 25, 523547.

Quintana-García, C., \& Benavides-Velasco, C.A. (2016). Gender Diversity in Top Management Teams and Innovation Capabilities: The Initial Public Offerings of Biotechnology Firms. Long Range Planning, 49, 507-518.

Rozeff, M.S. (1982). Growth, Beta and Agency Costs as Determinants of Dividend Payout Ratios. Journal of Financial Research, 5, 249-259.

Saeed, A., \& Sameer, M., (2017). Impact of Board Gender Diversity On Dividend Payments: Evidence From Some Emerging Economies. International Business Review, 26, 1100-1113. 
Sakai, M., \& Fauzia, A. (2016). Performing Muslim Womanhood: Muslim Business Women Moderating Islamic Practices in Contemporary Indonesia. Islam and Christian-Muslim Relations, 27, 229-249.

Sanan, N.K. (2019). Impact of Board Characteristics on Firm Dividends: Evidence from India. Corporate Governance: The International Journal of Business in Society, $19,1204-1215$.

Smith, N. (2018). Gender Quotas on Boards of Directors. IZA World of Labor 7.

Solal, I., \& Snellman, K. (2019). Women Don't Mean Business? Gender Penalty in Board Composition. Organization Science, 30, 1270-1288.

Srinidhi, B., Sun, Y., Zhang, H., \& Chen, S. (2020). How Do Female Directors Improve Board Governance? A Mechanism Based on Norm Changes. Journal of Contemporary Accounting E Economics, 16, 100181.

Von Eije, H., \& Megginson, W.L. (2008). Dividends and Share Repurchases in the European Union. Journal of Financial Economics, 89, 347-374.

Wang, G., DeGhetto, K., Ellen, B.P., \& Lamont, B.T. (2019). Board Antecedents of CEO Duality and the Moderating Role of Country-level Managerial Discretion: A Meta-analytic Investigation. Journal of Management Studies, 56, 172-202.

Wardhana, L.I., \& Tandelilin, E. (2018). Do We Need a Mandatory Dividend Regulation? The Case of the Indonesian Capital Market. Gadjah Mada International Journal of Business, 20, 33-68.

Wu, D.-M. (1973). Alternative Tests of Independence between Stochastic Regressors and Disturbances. Econometrica, 41, 733-750.

Yan, J., \& Sorenson, R.L. (2004). The Influence of Confucian Ideology on Conflict in Chinese Family Business. International Journal of Cross Cultural Management, 4, 5-17.

Ye, D., Deng, J., Liu, Y., Szewczyk, S.H., \& Chen, X. (2019). Does Board Gender Diversity Increase Dividend Payouts? Analysis of Global Evidence. Journal of Corporate Finance, 58, 1-26.

Yoshikawa, T., \& Rasheed, A.A. (2010). Family Control and Ownership Monitoring in Family-Controlled Firms in Japan. Journal of Management Studies, 47, 274-295. 
This page is intentionally left blank 